\title{
Genetic Versus Environmental Influence on Radial Variation in Myracrodruon urundeuva Wood
}

\author{
Eduardo Luiz Longui ${ }^{1}$, Gabriela Trindade Pires ${ }^{1}$, Miguel Luiz Menezes Freitas ${ }^{1}$, \\ Diego Romeiro ${ }^{1}$, Sandra Monteiro Borges Florsheim ${ }^{1}$, \\ Antonio Carlos Scatena Zanatto ${ }^{2}$ \\ ${ }^{1}$ Divisão de Dasonomia, Instituto Florestal, São Paulo/SP, Brazil \\ ${ }^{2}$ Divisão de Florestas e Estações Experimentais, Instituto Florestal, Luiz Antônio/SP, Brazil
}

\begin{abstract}
We hypothesized that Myracrodruon urundeuva trees of two provenances with different genotypes would present variations influenced by their origin terms of anatomy and specific gravity when planted in an environment different from their seed origin, but under the same environmental conditions. We investigated radial variation in 12 trees. The observation that only vessel frequency and fiber length showed the same pattern of radial variation in the two provenances indicate that radial variation in $M$. urundeuva seems to depend on the origin of the seeds, that is, a genetic factor, rather than on the influence of climate and soil, which repreent environmental factors. We noticed marked differences in all features when comparing the same growth rings in each provenance, a result that reinforces the genetic influence on wood formation. We conclude that the studied plants maintain their wood structure as a result of genetic information, as selected by climatic conditions of seed original area, and possibly due to the highly conservative wood anatomy.
\end{abstract}

Keywords: aroeira, plant breeding, tropical woods, wood properties.

\section{Influência Genética Versus Ambiental Sobre a Variação Radial na Madeira de Myracrodruon urundeuva}

\begin{abstract}
RESUMO
Hipotetizamos que árvores de Myracrodruon urundeuva de duas procedências com genótipos diferentes, apresentem variações anatômicas e na densidade aparente quando plantadas em ambiente diferente da origem de suas sementes, mas nas mesmas condições ambientais. Investigamos a variação radial em 12 árvores. Nossos resultados sugerem que a variação radial em $M$. urundeuva parece depender mais da origem das sementes, um fator genético, do que da influência do clima e do solo, um fator ambiental, pois só a frequência de vasos e comprimento das fibras mostraram o mesmo padrão de variação radial nas duas procedências. Ao comparar os mesmos anéis de crescimento em cada procedência, notam-se diferenças em todas as características, o que reforça as influências genéticas sobre a formação da madeira. Concluiu-se que as plantas mantêm a estrutura de madeira a partir da informação genética selecionada pelas condições climáticas da região de origem das sementes, devido à natureza conservativa da madeira.
\end{abstract}

Palavras-chave: aroeira, melhoramento de plantas, madeiras tropicais, propriedades da madeira. 


\section{INTRODUCTION}

Tree breeding programs require the study of the influences of environment and genetics in the context of wood anatomic features and properties of different species. The results of these studies may provide a guide for planting a particular species in a location that produces the best wood quality for a specific application. Such information is also important for reforestation, as it might indicate which populations of a particular species will have greater competitive success, as well as improve the chance that their offspring will grow and develop adequately in specific areas, enabling proper matrix selection for seeds. Thus, provenance tests can provide silvicultural and wood quality knowledge to explore the variability and the conservation of genetic material for future use.

During plant growth and development, wood formation, morphology and anatomy are influenced by genetic factors, environmental factors such as rainfall, temperature and soil water availability, as well as geographic factors (Fisher et al., 2007). Some of the main causes of genotype versus environment interaction are predictable factors such as photoperiod, soil type and soil fertility, but others are unpredictable factors, as rainfall distribution, relative humidity and atmospheric temperature (Borém \& Miranda 2013). While some wood features respond to environmental variations and show adaptations that allow greater fitness in certain environments (Pratt et al., 2007), other features, such as density, show high heritability and low phenotypic plasticity within species, irrespective of environmental impositions (Cornelius 1994; Chave et al., 2006). However, variations in density have to be interpreted along with anatomical features because both determine wood density.

Wood structure seems to possess more conservative features than those of external morphology. As a consequence, specific differences are often less clearly expressed in the wood than in the external features that experience greater selection pressure (Metcalfe \& Chalk 1957; Herendeen \& Miller 2000). Heritabilities change with the environment such that the greater the effect of the environment, the smaller will be the heritability value. Because of the many environmental factors that affect heritability, there is always uncertainty as to what extent heritability values determined for one area represent those from another area (Zobel \& Jett, 1995). Although the theory makes clear distinction between genetic and environmental control, in practice we are not always able to discern which type of control is acting (Lachenbruch et al., 2011).

Therefore, in order to study the effect of seed provenance on wood anatomical features and specific gravity in trees planted in an environment different from their seed origin, we chose a native species to Brazil named Myracrodruon urundeuva Allemão (Anarcadiaceae) and popularly known as "aroeira" (Lorenzi, 1992; Andrade et al., 2000). Tree height can reach $30 \mathrm{~m}$ and varies according to the region of occurrence (Rizzini, 1971). M. urundeuva is widely distributed and occurs in Argentina, Bolivia, Paraguay and Mexico (Alice Software, 2004). In Brazil, the species can be found in the Northeast, Midwest and Southeast, occurring in Caatinga, Cerrado and the Atlantic Rain Forest (Silva-Luz \& Pirani, 2013).

Radial variation in tree trunk has been studied to aid the choice of plants that have commercial importance, making it possible to establish the most suitable raw material for a given application. These investigations have helped improving the understanding of anatomical differences and wood properties found on plantations (Bosman et al., 1994) where different spacing is employed, in contrast to trees growing in natural forests.

M. urundeuva heartwood is rot-proof. The high amount of phenolic extractives associated with lignin probably accounts for the high natural wood resistance (Queiroz et al., 2002). Furthermore, the superior strength of the wood has, in the past, contributed to make it the choice in building construction (Lorenzi, 1998). Unfortunately, natural populations have been devastated as a result of uncontrolled exploitation and large trees have been virtually extinguished (Brandão, 2000). Currently, M. urundeuva is considered endangered and categorized as vulnerable in Brazil (Mendonça \& Lins, 2000).

To protect the genetic resources of this and other Brazilian tree species and for studies in various fields, the São Paulo Forest Institute in Brazil has developed a program since 1979 to conserve tree species native to Brazil (Gurgel-Garrido et al., 1997; Sebbenn et al., 2001). This program has allowed us to evaluate the effect of seed provenance on wood anatomy and properties (Longui et al., 2011). 
We hypothesized that M. urundeuva trees of two provenances with different genotypes would present variations influenced by their origin in terms of anatomy and specific gravity when planted in an environment different from their seed origin, but under the same environmental conditions. This statement is based on the fact that the wood presents a strongly conserved nature.

\section{MATERIAL AND METHODS}

Seed provenance, planting area and sampling - Openpollinated seeds were collected from M. urundeuva natural populations in two municipalities in São Paulo State, Brazil: Ilha Solteira (IS) seeds collected in 1987, and Pederneiras (PE) seeds collected in 1992. Seedlings were produced and planted at the Luiz Antônio Experimental Station, Luiz Antônio City, São Paulo, in two periods (Ilha Solteira provenance in 1988 and Pederneiras provenance in 1993) (Figure 1).

The mean temperature and precipitation in Luiz Antônio city were obtained from CEPAGRI (2013). Based on temperature and precipitation, the water balance of Thornthwaite \& Mather (1955) was prepared using the spreadsheet by Rolim et al. (1998). Temperature, precipitation, water deficit and water surplus for the three areas are shown in Figure 2.

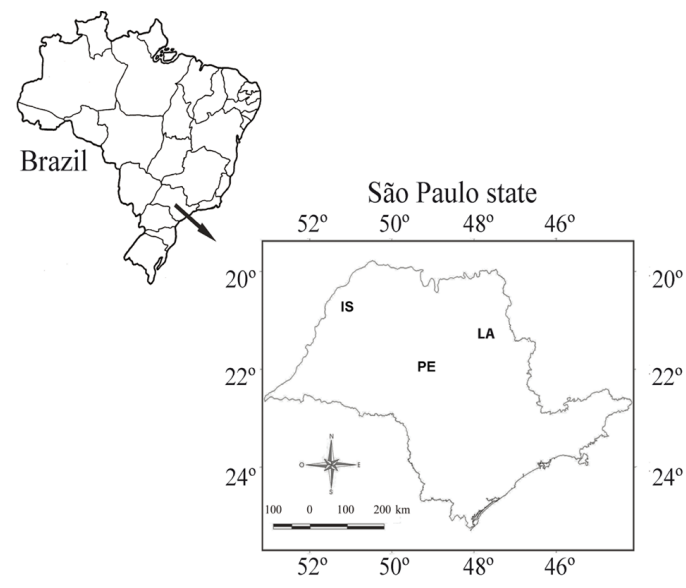

Figure 1. Location of the two seed collection areas - Ilha Solteira (IS) in 1987 and Pederneiras (PE) in 1992 - and the area of tree growth, Luiz Antônio (LA), in São Paulo State, Brazil. Seedling planting was conducted in 1988 in Ilha Solteira and in 1993 in Pederneiras.
A total of 12 trees, six from each provenance, were collected in February 2011, and from each tree, a disc about $10 \mathrm{~cm}$ thick was taken at breast height (DBH, $1.3 \mathrm{~m}$ from the ground). We used both electric planer and sandpaper to prepare each disc. We then investigated the growth rings using a 10x hand lens and stereomicroscope. Then we cut out a strip, which was divided in two halfs (transversely): the top was used for anatomical analysis and the bottom for specific gravity determination (Figure 3 ).
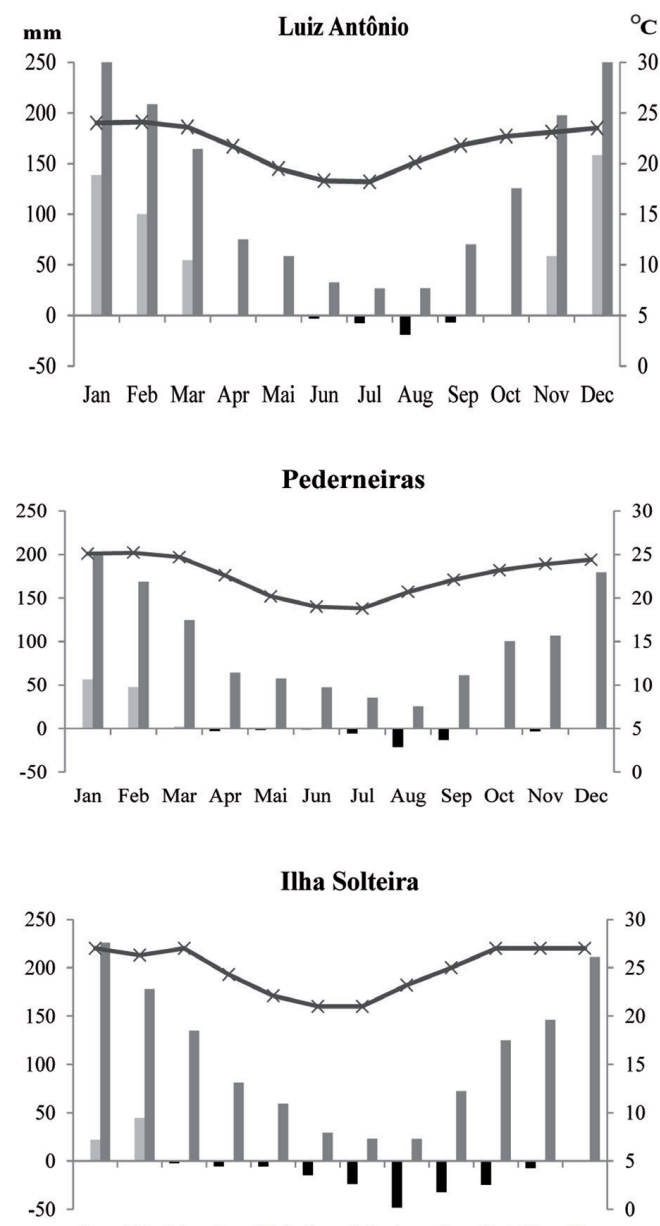

Jan Feb Mar Apr Mai Jun Jul Aug Sep Oct Nov Dec

$\square$ DEF(-1) EXC Precipitacion $\nleftarrow$ Temperature

Figure 2. Average monthly precipitation, water deficit (DEF-1), water surplus (EXC) in bars, and mean temperature in lines of the three areas: the areas of seed collection - Ilha Solteira and Pederneiras - and the area of tree growth - Luiz Antônio - 1961-1990 (CEPAGRI, 2013). Water balance of Thornthwaite \& Mather (1955) was prepared using the spreadsheet by Rolim et al. (1998). 


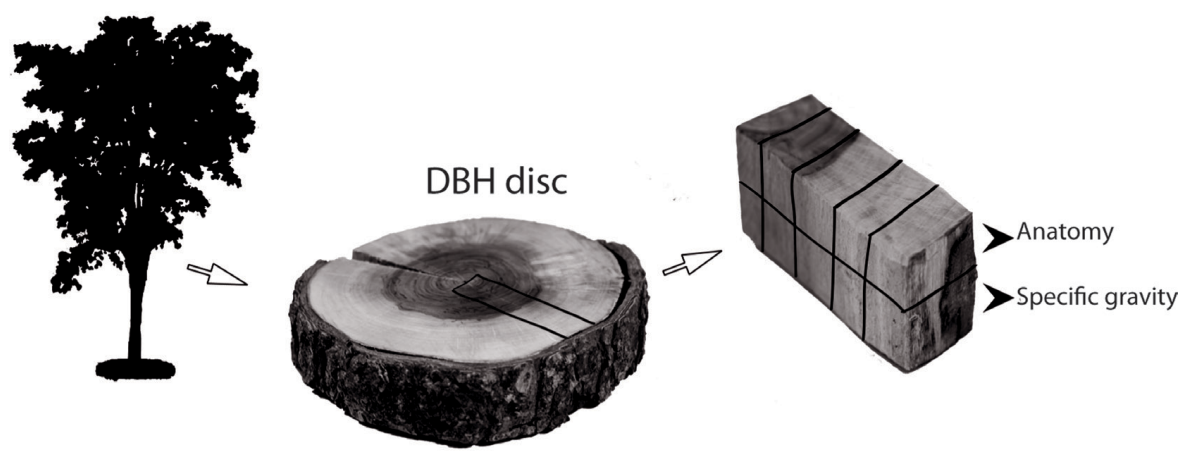

Figure 3. Schematic illustration of samples for anatomy measurements and specific gravity estimation. We cut a disc at breast height (DBH, $1.3 \mathrm{~m}$ from the ground) in each tree. Each sample contained $4 \pm 1$ growth rings. We also adopted the proximity in sampling (top and bottom) to relate the specific gravity with the anatomical features.

From the top part, we cut samples from pith to bark, and each sample contained $4 \pm 1$ growth rings. However, because of the difference in the ring number among discs (21 and 17 growth rings for Ilha Solteira and Pederneiras, respectively), we collected a different number of samples for each disc: six trees with five radial samples totaling 30 samples in Ilha Solteira; and six trees with four radial samples totaling 24 samples in Pederneiras. Bottom samples were divided into three equal parts for specific gravity determination. We adopted the proximity in sampling to relate specific gravity with anatomical features.

For anatomical measurements, we softened blocks of $2 \mathrm{~cm}^{3}$ in boiling water and glycerin (4:1) and cut 20-25 $\mu \mathrm{m}$ thick sections on a sliding microtome. The transverse and longitudinal sections (A) were bleached with $60 \%$ sodium hypochlorite and washed in water (Johansen, 1940). We prepared macerations (B) according to the modified Franklin method (Berlyn \& Miksche, 1976). Then, we stained A and B with aqueous safranin and mounted in a solution of water and glycerin (1:1). The terminology and characterization of wood followed the quantitative features of IAWA list (IAWA Committee, 1989). Vessel diameter, vessel frequency, vessel element length, fiber length, fiber wall thickness, ray height, ray width and ray frequency were obtained from a microscope (Olympus CX 31) equipped with a camera (Olympus Evolt E330) and a computer with image analyzer software (Image-Pro 6.3).

Specific gravity was determined according to Glass $\&$ Zelinka (2010). This property is defined as the ratio of the density of a substance to the density of water $\rho_{w}$ at a specified reference temperature, typically $4^{\circ} \mathrm{C}$, where $\rho_{\mathrm{w}}$ is $1.000 \mathrm{~g} \mathrm{~cm}^{-3}$ or $1,000 \mathrm{~kg} \mathrm{~m}^{-3}$. Therefore, a material with a density of $5 \mathrm{~g} \mathrm{~cm}^{-3}$ has a specific gravity of 5. Samples of $2 \times 2 \times 3 \mathrm{~cm}$ were dried at standard temperature to reach about $12 \%$ moisture content. Then, the oven-dry mass of samples and volume displaced by immersion in water were determined with a semi-analytical balance.

We evaluated radial variation in each provenance by employing a Normality Test and an Equal Variance Test, and then a One Way Analysis of Variance. When significant differences were observed, we used Multiple Comparison Procedures (Tukey test) to identify the determinant pair of differences. In comparisons of radial positions between trees from the two provenances, e.g., growth ring 4 (IS) compared to growth ring 4 (PE), the t-test was used. Regression analysis between anatomical features and specific gravity was also performed. Results with $\mathrm{P}<0.05$ were considered significant.

\section{RESULTS}

We measured the height and diameter at breast height in all trees (Table 1).

Radial position in each provenance - Vessel diameter increased gradually toward the bark in IS, while the changes were abrupt in PE (Figure 4a). Vessel frequency decreased toward the bark in both provenances (Figure 4b). The radial pattern of vessel element length differed between the provenances from the fourth to the eighth growth ring, with a decreasing trend in IS and an increasing trend in PE (Figure 4c).

Fiber length increased toward the bark in both provenances (Figure 4d). While fiber wall thickness 
Table 1. Dendrometric data of 23-year-old (Ilha Solteira) and 18-year-old (Pederneiras) Myracrodruon urundeuva trees.

\begin{tabular}{|c|c|c|c|c|c|}
\hline \multicolumn{3}{|c|}{ Ilha Solteira } & \multicolumn{3}{|c|}{ Pederneiras } \\
\hline Tree & Height (m) & DBH $(\mathrm{cm})$ & Tree & Height (m) & DBH $(\mathrm{cm})$ \\
\hline 1 & 18.6 & 28 & 1 & 17.8 & 22 \\
\hline 2 & 18.1 & 23 & 2 & 18.0 & 19 \\
\hline 3 & 19.0 & 26 & 3 & 19.9 & 27 \\
\hline 4 & 20.1 & 28 & 4 & 18.6 & 21 \\
\hline 5 & 19.0 & 25 & 5 & 16.2 & 20 \\
\hline 6 & 19.5 & 20 & 6 & 19.1 & 20 \\
\hline Mean & 19.0 & 25 & Mean & 18.2 & 21.5 \\
\hline
\end{tabular}

$\mathrm{DBH}=$ diameter at breast height.
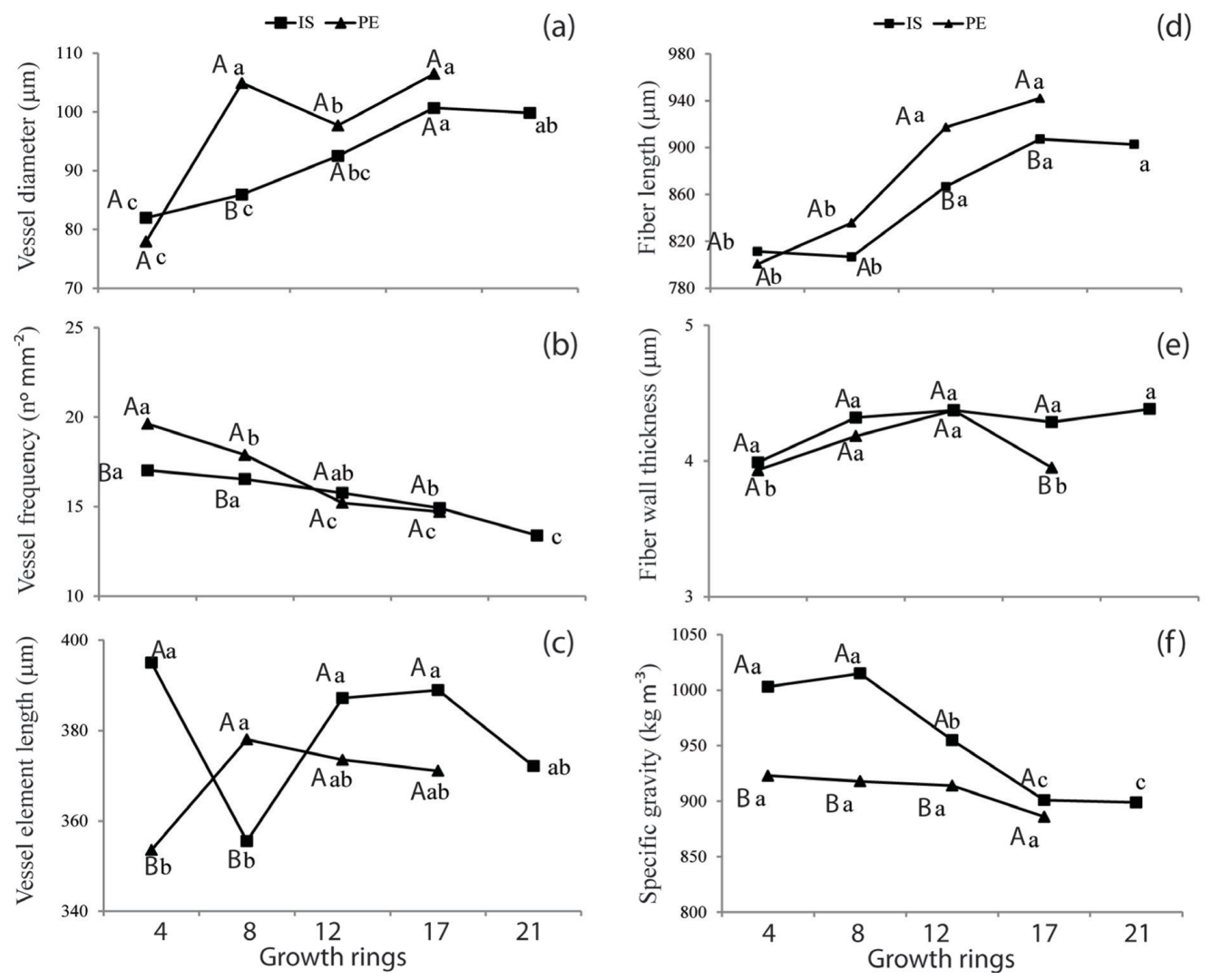

Figure 4. Radial variation of vessel (a-c) and fiber (d-e) features and specific gravity (f) in the two provenances (IS = Ilha Solteira; PE = Pederneiras). Different letters in the same line differ statistically, results with $\mathrm{P}<0.05$ were considered significant; Tukey test for radial variation in each provenance (lowercase) and t-test for comparison between provenances in each position (uppercase).

did not vary in IS, lower values in pith and bark were observed in PE (Figure 4e).

Specific gravity was higher until the eighth growth ring, and the lowest value was observed from the seventeenth growth ring to near the bark in the IS provenance. Specific gravity showed no significant difference from pith to the bark in PE (Figure 4f).
We highlight the lack of radial variation for width and frequency of rays in PE (Figure 5a-c). Specific gravity showed a negative correlation with ray height (Figure 6).

Radial position comparing provenances - Vessel diameter in growth ring 8 of the PE provenance was larger than the growth ring 8 in IS (Figure 4a). Vessel 

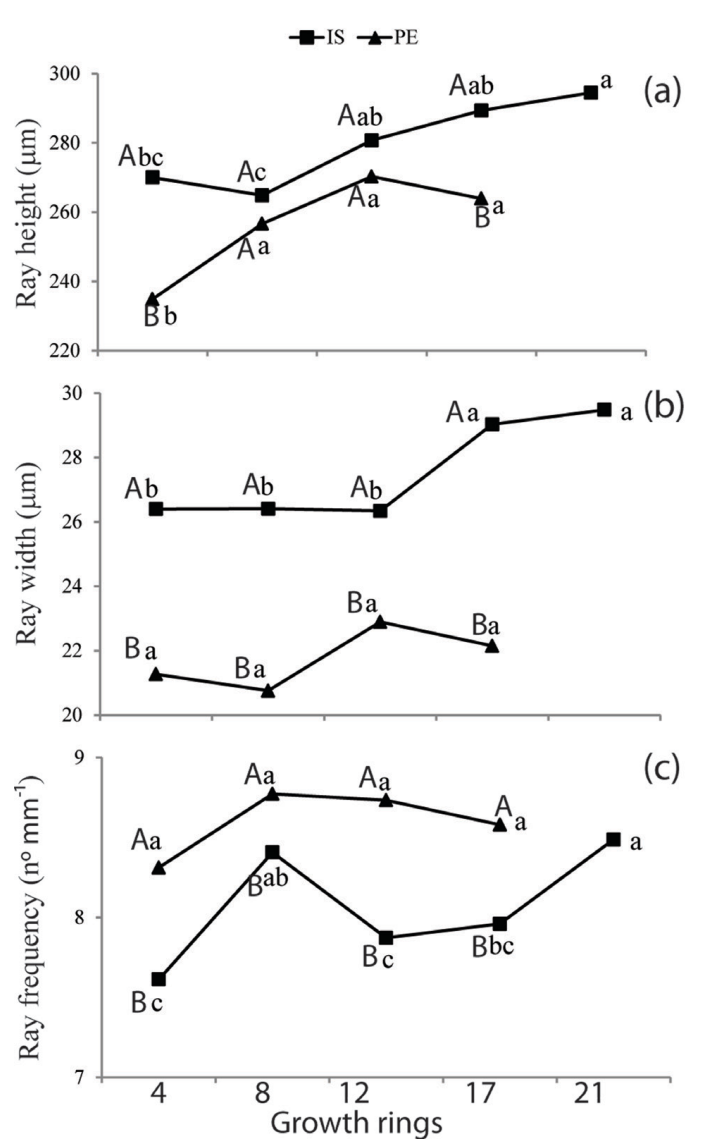

Figure 5. Radial variation of ray features in the two provenances (IS = Ilha Solteira; PE = Pederneiras). Different letters in the same line differ statistically, results with $\mathrm{P}<0.05$ were considered significant; Tukey test for radial variation in each provenance (lowercase) and t-test for comparison between provenances in each position (uppercase).

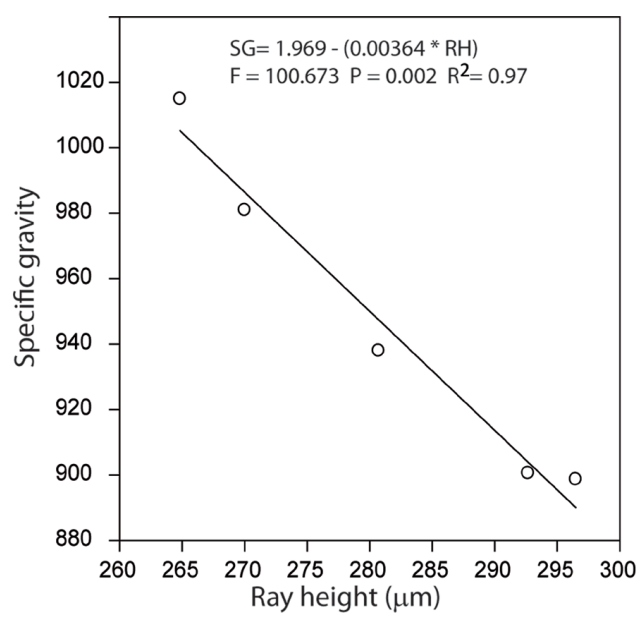

Figure 6. Specific gravity as a function of ray height in Ilha Solteira provenance. frequency was higher in growth rings 4 and 8 in PE compared with IS (Figure 4b). Vessel element length varied between provenances; longer cells in the growth ring 4 and shorter cells in the growth ring 8 were noted in IS (Figure 4c).

Longer fibers in growth rings 12 and 17 were observed in the PE provenance (Figure 4d). Fiber wall thickness was higher in growth ring 17 in the IS provenance (Figure 4e). Specific gravity was higher from growth ring 4 to growth ring 12 in IS, but no difference was observed between provenances in the growth ring 17 (Figure 4f).

Ray height in growth rings 4 and 17 was higher in IS (Figure 5a). Ray width was larger in IS (Figure 5b), but ray frequency was higher in PE (Figure 5c) in all growth rings.

\section{DISCUSSION}

Radial variation in many wood anatomy features is a common phenomenon. However, the proportion of radial variation patterns that are fixed, as opposed to those that are plastic, in relation to the environment of plant growth remains a controversial issue (Lachenbruch et al., 2011). In our study, only vessel frequency and fiber length showed the same radial variation pattern between the two provenances (Pederneiras and Ilha Solteira), although when comparing the growth rings among the provenances we noticed variations in all features (represented in the graphs by capital letters). This leads us to question whether this resulted from genetic control established by the environmental constraints to which the mother plants and their ancestors were subjected over time or an expression of phenotypic plasticity. We hypothesized that M. urundeuva trees of two provenances with different genotypes would present variations influenced by origin in anatomy and specific gravity when planted in an environment different from their seed origin, but under the same environmental conditions. To test this hypothesis, we studied trees of two different climatic origins (Ilha Solteira and Pederneiras provenances) planted in a third area (Luz Antonio), but under the same environmental conditions, e.g., temperature, precipitation and soil. The climatic diagram of the three areas showed a greater similarity between Pederneiras and Luiz Antônio (Figure 2), but with less water deficit than that of Ilha Solteira, 
possibly resulting in more homogeneity in Pederneiras wood. This was indicated by the absence of significant variation in four features: width, height and frequency of rays, and specific gravity. We emphasize that Ilha Solteira has an important water deficit from April to November; thus, it is possible that this restriction over the years could have acted as a selective force towards safety against the risk of embolisms. In this regard, the comparatively small diameter of vessels in IS wood, in contrast to that from PE, can be seen in Figure 4a.

Tung et al. (2010) reported the genetic variation in M. urundeuva for silvicultural parameters. While studying vessel diameter and vessel frequency from pith to bark, they noted that heritability of vessel diameter was high in pith, then decreased and increased again near the bark, with values close to the pith, while heritability in vessel frequency was high in pith and very low toward the bark. According to Lenz et al. (2010), when a feature is highly heritable, it is more likely to be influenced by ontogeny. However, in the case of low heritability, phenotypic plasticity was more likely to occur. Based on this statement, it appears that vessel diameter, in comparison to vessel frequency, is more genetically than environmentally controlled in the studied trees.

The inverse relationship between diameter (increase) and frequency (decrease) of the vessels toward the bark found in this study was also observed by Florsheim et al. (1999) in 26-year-old M. urundeuva, while Tung et al. (2010) observed a decrease in both diameter and vessel frequency toward the bark in 10-year-old M. urundeuva planted in Ilha Solteira. It is notable that seeds in the Tung study were collected from trees grown in Selvíria municipality, Mato Grosso State, which borders Ilha Solteira and, therefore, possibly came from the same $M$. urundeuva population with the same genetic characteristics of trees that gave rise to the trees evaluated in our study. This result indicates that the pattern of variation in vessel diameter, at least in the studied M. urundeuva population, is influenced by the environment. This conclusion is based on the decrease in both frequency and diameter of vessels in the Tung et al. (2010) study based on seeds collected from trees grown in Selvíria municipality. In our study, seeds that originated from the neighboring Ilha Solteira were planted at Luiz Antônio, and we found an inverse relationship between vessel diameter and frequency toward the bark. We speculate that the strong water restriction in Ilha Solteira may have contributed to this result, particularly because Hacke et al. (2005) have argued that larger diameter vessels are more susceptible to the risk of embolisms.

Radial variation of rays was also different between the two provenances, especially when we analyzing width and frequency of rays among the provenances (uppercase in graphs). Highlighting the lack of radial variation for width and frequency in the PE provenance, Florsheim et al. (1999) reported higher and wider rays near the bark of 26-year-old M. urundeuva, which partially corroborates our results. Florsheim's study also reported lower ray frequency near the bark, a result contrary to the present studied trees originally from Ilha Solteira provenance. We found no studies on heritability of ray features, but the difference between the two provenances leads us to speculate about the influence of genetics acting on ray features of the trees studied. With that in mind, some hypotheses may be formulated to explain the results for the rays, for example: 1) the lack of variation in ray frequency and width in PE could also be considered as a genotypic variation of the species, according to the adaptive origin of the seed area, 2) ray size could be affected by a gradual decrease of IAA and gradual increase of ethylene synthesis, hormones related to natural gradual increase in ray size from pith to bark (Aloni, 2007), and 3) homogeneous rays along the radial growth could result from the lack of variation or stability in IAA and ethylene levels.

Our results showed the same pattern for fiber length between the two provenances, but fiber wall thickness did not vary in IS. Although the pattern is the same, the differences between growth rings can be seen: in the ring 12 for length, and in the ring 17 for fiber wall thickness (uppercase in graphs). We point to this result as another indicator of genetic influence, particularly because variations in fiber features, especially increased cell length toward the bark, is common in the radial growth of many species, as observed by Florsheim \& Tomazello-Filho (1996) in 26-year-old M. urundeuva and others studies conducted by our group with other Brazilian species analyzed in the same growing conditions: Balfourodendron riedelianum and Cariniana legalis (Lima et al., 2011a, b, respectively) and Gallesia integrifolia (Longui et al., 2011). Since fiber proportion gradually increased toward the bark and since these cells are directly related to wood structure 
maintenance, it is possible that $M$. urundeuva radial variation serves mostly to maintain the tree's structural integrity, a hypothesis put forth by Lachenbruch et al. (2011), in particular because M. urundeuva wood is recognized for its high mechanical strength.

Specific gravity decreased towards the bark in trees with seeds originating from IS, as also reported by Florsheim \& Tomazello-Filho (1998) in 26-year-old M. urundeuva ( 0.80 to $\left.0.66 \mathrm{~g} . \mathrm{cm}^{-3}\right)$ and by Tung et al.

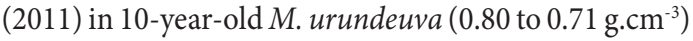
planted in Ilha Solteira (IS), the same municipality in which we collected seeds planted in Luiz Antônio in this study. Despite the same pattern of variation, the difference between the growth rings of the provenances was evident. Tung et al. (2011) reported high heritability for specific gravity near the pith and in the intermediate region, indicating strong genetic control. Our result, in which specific gravity showed a negative correlation with ray height in IS, may also be related to the high concentration of tyloses in the pith and higher content of extractives contributing to the darker coloration typical of $M$. urundeuva heartwood.

Trees from seeds originating from PE did not show radial variation in specific gravity, possibly because of the greater homogeneity of anatomical features that directly affect wood specific gravity. In another study, we did not observe changes in specific gravity or anatomical features in Peltophorum dubium from two provenances, Alvorada do Sul municipality, Paraná State, and Bauru municipality, São Paulo State (more than $200 \mathrm{~km}$ apart from each other), both planted in Luiz Antônio (Lima et al., 2015). Sebbenn et al. (2009), who studied the silvicultural behavior and interactions between genotype and environment using the same Peltophorum dubium populations also found no genetic differences.

Based on the study of Tung et al. (2010), we speculate that oscillation of genetic/environmental influence should occur in the radial direction also to the rays, fibers and hence the specific gravity in wood formation of $M$. urundeuva. It is possible that the difference in the radial pattern between the two provenances is related to environmentally induced changes in gene (Day \& Greenwood, 2011).

No variations in anatomical features (same of present study) and specific gravity between provenances have been found for 28-year-old Peltophorum dubium trees also planted in Luiz Antônio (Lima et al., 2015), possibly due to lack of genetic variation between the two populations. Thus, the results of this study are very important for selection of $M$. urundeuva matrices. Our results show that Pederneiras wood was more homogeneous than Ilha Solteira wood, leading to the conclusion that the studied plants maintain their wood structure as a result of genetic information, as shaped by climatic conditions of seed original area, and possibly due to the highly conserved wood anatomy when compared to other plant parts.

\section{CONCLUSIONS}

Radial variation in Myracrodruon urundeuva seems to depend more on the origin of the seeds (genetic factor) than on the influence of climate and soil of Luiz Antônio (environmental factor) because only vessel frequency and fiber length showed the same pattern of radial variation between the two provenances. When comparing the same growth rings in each provenance, we noticed marked differences in all features, a result that reinforces the genetic influence on wood formation.

\section{ACKNOWLEDGEMENTS}

We are grateful to the Conselho Nacional de Desenvolvimento Científico e Tecnológico - CNPq "National Council for Scientific and Technological Development" for a grant to Gabriela Trindade Pires (114618/2011-9), and we are especially grateful to Israel Luiz de Lima for fieldwork, Sonia Godoy Campião and Ekton Passo for laboratory assistance.

\section{SUBMISSION STATUS}

Received: 03 nov., 2014

Accepted: 26 june, 2016

\section{CORRESPONDENCE TO}

\section{Eduardo Luiz Longui}

Divisão de Dasonomia, Instituto Florestal, Rua do Horto, 931, CEP 02377-000, São Paulo, SP, Brazil e-mail: edulongui@gmail.com 


\section{REFERENCES}

Alice Software. Myracrodruon urundeuva Fr. All. [online] 2004. [cited 2012 Jan 25]. Available from: http://www. alicesoftware.com/webs/trees/aweb/td001/td_00045.html

Aloni R. Phytohormonal mechanisms that control wood quality formation in young and mature trees. In: The Compromised Wood Workshop; 2007; Christchurch. Christchurch: Wood Technology Research Centre, University of Canterbury; 2007. p. 1-22.

Andrade MW, Luz JMQ, Lacerda AS, Melo PRA. Micropropagação da aroeira (Myracrodruon urundeuva Fr. All.). Ciência e Agrotecnologia 2000; 24: 174-180.

Berlyn GP, Miksche JP. Botanical microtechnique and cytochemistry. Iowa: The Iowa University Press; 1976. 326 p.

Borém A, Miranda GV. Melhoramento de plantas. Viçosa: Editora UFV; 2013. 523 p.

Bosman MTM, Kort I, van Genderen MK, Baas P. Radial variation in wood properties of naturally and plantation grown light red meranti (Shorea sp., Dipterocarpaceae). IAWA Journal 1994; 15(2): 111-120. http://dx.doi. org/10.1163/22941932-90001350.

Brandão M. Caatinga. In: Mendonça MP, Lins LV, organizadores. Lista vermelha das espécies ameaçadas de extinção da flora de Minas Gerais. Belo Horizonte: Fundação Biodiversitas; Fundação Zôo-Botânica de Belo Horizonte; 2000. p. 75-85.

Centro de Pesquisas Meteorológicas e Climáticas Aplicadas a Agricultura - CEPAGRI. Clima dos Municípios Paulistas [online]. Campinas: CEPAGRI; 2013. [cited 2013 Feb 21]. Available from: http://www.cpa.unicamp.br/outrasinformacoes/clima-dosmunicipios-paulistas.html

Chave J, Muller-Landau HC, Baker TR, Easdale TA, Steege HT, Webb CO. Regional and phylogenetic variation of wood density across 2456 neotropical tree species. Ecological Applications 2006; 16(6): 2356-2367. PMid:17205910. http://dx.doi.org/10.1890/1051-0761(2006)016[2356:RA PVOW]2.0.CO;2.

Cornelius J. Heritabilities and additive genetic coefficients of variation in forest trees. Canadian Journal of Forest Research 1994; 24(2): 372-379. http://dx.doi.org/10.1139/ x94-050.

Day ME, Greenwood MS. Regulation of ontogeny in temperate conifers. In: Meinzer FC, Lanchenbruch B, Dawson TE, editors. Size-and age-related changes in tree structure and function. London: Springer; 2011.p. 91-120.

Fisher JB, Goldstein G, Jones TJ, Cordell S. Wood vessel diameter is related to elevation and genotype in the Hawaiian tree Metrosideros polymorpha (Myrtaceae). American Journal of Botany 2007; 94(5): 709-715. PMid:21636440. http://dx.doi.org/10.3732/ajb.94.5.709.
Florsheim SMB, Tomazello-Filho M, Spegiorin L. Variação das dimensões no sentido medula-casca e base-topo de árvores de "aroeira" Myracrodruon urundeuva F.F. \& M.F. Allemão (Anacardiaceae). II. Vasos e raios. Revista do Instituto Florestal 1999; 11: 159-171.

Florsheim SMB, Tomazello-Filho M. Variação das dimensões no sentido medula-casca e base-topo de árvores de "aroeira" Myracrodruon urundeuva F.F. \& M.F. Allemão (Anacardiaceae). Revista do Instituto Florestal 1996; 8(2): 153-165.

Florsheim SMB, Tomazello-Filho M. Variação da densidade básica da madeira de aroeira Myracrodruon urundeuva F.F. \& M.F. Allemão (Anacardiaceae). Revista do Instituto Florestal 1998; 10: 53-61.

Glass S, Zelinka SL. Moisture relations and physical properties of wood. In: Ross R, editor. Wood handbook: wood as an Engineering Material. Geneva: United States Department of Agriculture; 2010. Centennial Edition, FPL-GTR-190. chapt 4.

Gurgel-Garrido LMA, Siqueira ACMF, Cruz SF, Romanelli RC, Ettori LG, Crestana CSM et al. Programa de melhoramento genético florestal do Instituto Florestal. IF Série Registros 1997; 18: 1-53.

Hacke UG, Sperry JS, Pittermann J. Efficiency versus safety tradeoffs for water conduction in angiosperm vessels versus gymnosperm tracheids. In: Holbrook NM, Zwienniecki MA, editors. Vascular transport in plants. Amsterdam: Elsevier Inc; 2005. p. 333-354.

Herendeen PS, Miller RB. Utility of wood anatomic characters in cladistic analysis. IAWA Journal 2000; 21(3): 247-276. http://dx.doi.org/10.1163/22941932-90000247.

IAWA Committee. List microscope features of hardwood identification. IAWA Bulletin 1989; 10(3): 219-332.

Johansen DA. Plant microtechnique. New York: McGrawHill; 1940. 533 p.

Lachenbruch B, Moore JR, Evans R. Radial variation in wood structure and function in woody plants, and hypotheses for its occurrence. In: Meinzer FC, Lanchenbruch B, Dawson TE, editors. Size-and age-related changes in tree structure and function. London: Springer; 2011. p. 121-164.

Lenz P, Cloutier A, MacKay J, Beaulieu J. Genetic control of wood properties in Picea glauca - an analysis of trends with cambial age. Canadian Journal of Forest Research 2010; 40(4): 703-715. http://dx.doi.org/10.1139/X10-014.

Lima IL, Longui EL, Cerato C, Freitas MLM, Florsheim $\mathrm{SMB}$, Zanatto ACS. Basic specific gravity and anatomy of Peltophorum dubium wood as a function of provenance and radial position. Revista do Instituto Florestal 2015; 27(1): 19-29. http://dx.doi.org/10.4322/rif.2015.002.

Lima IL, Longui EL, Garcia MF, Zanatto ACS, Freitas MLM, Florsheim SMB. Variação radial da densidade básica e dimensões celulares da madeira de Cariniana legalis (Mart.) O. Kuntze em função da procedência. 
Cerne 2011a; 17(4): 517-524. http://dx.doi.org/10.1590/ S0104-77602011000400010.

Lima IL, Mastelin SM, Longui EL, Freitas MLM, Romeiro D, Zanatto ACS et al. Densidade básica e dimensões celulares da madeira de Balfourodendron riedelianum em função da procedência e posição radial. Revista do Instituto Florestal 2011b; 23: 217-230.

Longui EL, Lima IL, Andrade IM, Freitas MLM, Florsheim $\mathrm{SMB}$, Zanatto ACS et al. Seed provenance influences the wood structure of Gallesia integrifolia. IAWA Journal 2011; 32(3): 361-374. http://dx.doi.org/10.1163/2294193290000064 .

Lorenzi H. Árvores brasileiras: manual de identificação e cultivo de plantas arbóreas nativas do Brasil. São Paulo: Plantarum; 1992. vol. 1, 368 p.

Lorenzi H. Árvores brasileiras: manual de identificação e cultivo de plantas arbóreas nativas do Brasil. 2. ed. Nova Odessa: Plantarum; 1998. vol. 1, 352 p.

Mendonça MP, Lins LV. Lista vermelha das espécies ameaçadas de extinção da flora de Minas Gerais. Belo Horizonte: Fundação Biodiversitas; 2000. 157 p.

Metcalfe CR, Chalk L. Anatomy of the dicotyledons. London: Claredon Press; 1957. vol. 1.

Pratt RB, Jacobsen AL, Ewers FW, Davis SD. Relationships among xylem transport, biomechanics and storage in stems and roots of nine Rhamnaceae species of the California chaparral. The New Phytologist 2007; 174(4): 787-798. PMid:17504462. http://dx.doi.org/10.1111/j.14698137.2007.02061.x.

Queiroz CRAA, Morais SAL, Nascimento EA. Caracterização dos taninos da aroeira-preta (Myracrodruon urundeuva). Revista Árvore 2002; 26(4): 485-492. http://dx.doi. org/10.1590/S0100-67622002000400011.

Rizzini CT. Árvores e madeiras úteis do Brasil. São Paulo: Edgard Blücher; 1971.
Rolim GS, Sentelhas PC, Barbieri V. Planilhas no ambiente EXCEL para os cálculos de balanços hídricos: normal, sequencial, de cultura e de produtividade real e potencial. Revista Brasileira de Agrometeorologia [online]. 1998 [cited 2013 Feb 21]; 6: 133-137. Available from: http://www.lce. esalq.usp.br/nurma.html

Sebbenn AM, Freitas MLM, Zanatto ACS, Moraes E, Moraes MA. Comportamento da variação genética entre e dentro de procedências e progênies de Gallesia integrifolia Vell. Moq. para caracteres quantitativos. Revista do Instituto Florestal 2009; 21: 151-163.

Sebbenn AM, Zanatto ACS, Ettori LC, Dio-Junior OJD. Ex situ genetic conservation of tree species at the São Paulo Forest Institute, Brazil. Forest Genetic Resources 2001; 29: 27-33.

Silva-Luz CL, Pirani JR. Anacardiaceae in Lista de Espécies da Flora do Brasil [online]. Rio de Janeiro: Jardim Botânico do Rio de Janeiro; 2013. [cited 2013 Apr 6]. Available from: http://floradobrasil.jbrj.gov.br/jabot/floradobrasil/FB4394

Thornthwaite CW, Mather JR. The water balance. New Jersey: Drexel Institute of Technology; 1955. 104 p. Publications in Climatology.

Tung ESC, Freitas MLM, Florsheim SMB, Lima IL, Longui EL, Moraes MLT et al. Variação genética para caracteres silviculturais e no diâmetro e frequência de vasos em progênies de Myracrodruon urundeuva (Engler) FR. Allem. Scientia Forestalis 2010; 38: 499-508.

Tung ESC, Freitas MLM, Florsheim SMB, Lima IL, Longui EL, Moraes MLT et al. Variação, divergência e correlações genéticas entre caracteres silviculturais e densidade básica da madeira em progênies de Myracrodruon urundeuva (Engler) Fr. Allem. Revista do Instituto Florestal 2011; 23: 1-12.

Zobel BJ, Jett JB. Genetics of wood production. Berlin: Springer-Verlag; 1995. 337 p. 